\title{
Between a camp and a hard place: rights, livelihood and experiences of the local settlement system for long-term refugees in Uganda
}

\author{
Tania Kaiser*
}

\section{A B S T R A C T}

Drawing on qualitative research with refugees in and outside formal settlements, this article challenges characterisations of Uganda's UNHCR-supported refugee settlement system as un-problematically successful. It shows that by denying refugees freedom of movement, the settlement system undermines their socioeconomic and other rights. Refugees who remain outside the formal system of refugee registration and settlement are deprived of the refugee status to which they are entitled under international law. The article questions the conventional opposition between refugees living in and out of refugee settlements in the Ugandan context, revealing a more complex and interconnected dynamic than is often assumed. It suggests that those refugees with some external support may be able to escape the confines of remote rural settlements, where refugee agricultural livelihoods are seriously compromised by distance from markets, unfavourable climatic conditions, exhausted soil and inadequate inputs. It argues that refugee livelihoods face more rather than fewer challenges as exile becomes protracted, and concludes that the government and UNHCR's Self Reliance Strategy (SRS) has not yet managed to overcome the contradiction inherent in denying people freedom of movement, without supporting them effectively to meet their needs in the places to which they are restricted.

\section{N T R O D U C T I O N}

Arguments about whether encampment is an appropriate, effective and ethical way of meeting the needs of refugees have raged at least since the early ig9os (Black I998; Crisp \& Jacobsen I998; Smith 2004; Van Damme

* School of Oriental and African Studies, University of London, and Research Associate of the Makerere Institute for Social Research. Thanks are due to colleagues at the Refugee Law Project, to all the refugees and others who generously gave their time to participate in the research, to the Uganda National Council for Science and Technology for research permission, and to staff at the Office of the Prime Minister and UNHCR. 
1995). Although few people position themselves as outright supporters of refugee camps, many conclude regretfully that they may be the only practicable response in a wide range of refugee situations. The alternative of supported self-settlement is rarely made explicit, and less frequently discussed with seriousness, or researched. ${ }^{1}$ Whatever theoretical position one takes in this debate, it is unarguably the case that in the context of an increasingly hostile protection environment in sub-Saharan Africa, few states show any signs of moving away from the encampment of refugees as their principal response in the short, medium and long term. States prefer the encampment of refugees for several related reasons; they offer visibility which helps with claims for burden sharing, they offer mechanisms for containment and control which help mitigate any perceived security threat in the short term, and they reduce the risk that refugee populations will melt into the host population, failing to repatriate when conditions change in the home country. There is significant evidence that this preference and policy is supported, if not actively encouraged, by the office of the United Nations High Commissioner for Refugees (UNHCR), the UN organisation mandated to protect refugees since 195I (HarrellBond i986; Marfleet 2006).

The terms of the encampment debate become complicated in today's increasingly common contexts of protracted exile, where the needs and desires of both refugees and their hosts are likely to change over time, and when the expectations of both groups may increase rather than decrease as time goes by. Sub-Saharan African states in particular face an increasing and intractable challenge in long-term refugee situations that have 'no solution in sight' (Crisp 2003). As Crisp notes, of the 3 million refugees stranded in protracted exile at the end of 200I, the vast majority were in Africa. It is entirely appropriate, therefore, that a wider and more varied range of responses have recently been sought to their predicaments. In the Ugandan as in many other contexts, however, as affected populations have, where possible, turned their attention towards developmental activities and outcomes, donors of previously humanitarian support have often become less interested in these populations, feeling that they are no longer the most needy. Recent re-consideration of the advantages of local integration as a durable solution (Jacobsen 200I) have overlapped to some extent with discussions about the benefits to be derived from facilitating camp-based 'self-sufficiency' or 'self-reliance' (with some measure of local integration usually assumed as a pre-requisite). While UNHCR (2005: 3) emphasises that 'self-reliance can be a precursor to any of the three durable solutions', in practice and in the Ugandan case, it is clear that repatriation remains the favoured solution. The conundrum for states has 
been to find a framework within which refugees can reasonably be expected to remain in government approved camps and settlements, and to achieve 'self-reliance' despite the in-built constraints of such economic environments.

In Uganda, attempts to square the circle of encampment and the need for refugee self-reliance have been expressed with respect to its three main refugee hosting districts (Arua, Moyo and Adjumani) in the language of development, decentralisation and the integration of services to refugees into district-level service provision and national poverty reduction strategies (OPM \& UNHCR 1999). The government's ad hoc policy of settlement for refugees has - via the mechanism of the 'Self Reliance Strategy' (SRS) - been married to a requirement that they support themselves with minimal external support in agricultural settlements. Whether this is a reasonable expectation, whether Uganda's settlements ever did or do still provide an adequate subsistence environment for long-term Sudanese refugees no longer in receipt of full food rations, and what alternatives are open to them, are the main concerns of this article.

\section{Sudanese refugees in Uganda}

Uganda, which neighbours Sudan and DRC on its north and northwestern border, has a long history of forced migration in both directions. Uganda hosted large numbers of Sudanese and then Zairian refugees in the I96os, while many Ugandans fled West Nile to those countries at the end of the I970s. Uganda has again hosted Sudanese since the late ig8os, and increased numbers of Congolese refugees since the ig9os. Almost all Ugandans living in the northern border region have either been refugees themselves, or have hosted refugees, at some point in their lives. ${ }^{2}$

The West Nile region has itself only fairly recently emerged from a turbulent and difficult period in its history. Arua District has experienced peace only since 2002, while Moyo District experienced a lesser degree of insurgency, but was effectively cut off economically from the rest of the country by the UNRF I and II rebellions, as well as by the LRA rebellion in neighbouring districts of northern Uganda. Adjumani district has experienced serious insecurity during the ongoing conflict between the LRA and the government of Uganda (GoU). However, the highly insecure conditions of other parts of the north are happily no longer to be found in West Nile. On the east of the Nile in the Districts of Gulu, Kitgum, Pader, Apac, Katakwi, Soroti and Lira, as many as $\mathrm{I} \cdot 6$ million are internally displaced by conflict, most of whom are confined to camp-like 'protected villages'. 
For most of the nearly 200,000 Sudanese refugees now living in settlements in Arua, Moyo, Koboko, Yumbe, Adjumani, Masindi and Hoima Districts, exile has been not only repeated, but also protracted. Sudan's internal conflict which re-ignited in 1983 forced millions to flee their homes, and a minority crossed international borders to neighbouring countries, including Uganda. The conflict is complex, and the direct causes and circumstances of flight were many and various (Johnson 2003). Some Sudanese have lived in a succession of transit camps, settlements and non-settlement locations, depending on changes in security conditions, government policy, personal circumstances and the availability of assistance. At the time of writing, a little over a year after the signing of the Comprehensive Peace Agreement in January 2005, a tri-partite agreement on repatriation has been signed between the governments of Sudan and Uganda and UNHCR, but continued insecurity in Sudan means that no refugees have yet been officially repatriated.

\section{The research}

The qualitative research on which this article is based was carried out in and outside refugee settlements in Arua District (now divided into Arua and Koboko Districts) in August 2004, and informed by six successive research trips and visits to Masindi District and other refugee hosting areas between 1996 and 2006. ${ }^{3}$ In Arua District, research was focused mainly in and around the settlements at Imvepi and Rhino Camp. Here a research team conducted formal and informal interviews with refugees, members of the host communities, government officials and aid workers, and held focus group and general discussion meetings. Where necessary, translators were drawn from either the refugee or the host communities (and occasionally from outside either community). The team was able to move freely throughout the settlements and benefited from the active support and facilitation of refugee leaders, as well as the willingness of ordinary people to engage with the research. Some time was also spent in urban, peri-urban and rural areas where 'self-settled' refugees were living in the district. In Masindi, numerous short research visits were made to the Kiryandongo Refugee Settlement, where the author also carried out ethnographic research from 1996 to $1997 .{ }^{4}$ Here, the author alone worked closely with members of the refugee community, relying on observation and casual interaction with community members, key informant interviews, and formal and informal interviews with stakeholders as listed above for Arua.

Arua currently hosts over 50,000 registered refugees in three refugee settlements (Imvepi, Rhino Camp, and Madi Okollo). ${ }^{5}$ Masindi is home to 
about ${ }_{15}$,000 registered refugees, living in the Kiryandongo Refugee Settlement. In both cases, many of the refugees have been in exile in Uganda for well over a decade, some arriving as early as I989, with others following more recently. An unspecified number of 'self-settled' refugees also live in both refugee hosting districts and urban areas. No quantitative research has been carried out in Uganda to ascertain exact numbers, which are estimated to be large on the basis of qualitative indicators and anecdotal evidence. The fact that the GoU and UNHCR refuse to register and assist refugees outside the context of the settlement system, and their uncertain legal status, provides a serious disincentive to self-settled refugees making themselves known to the authorities or researchers.

The rest of the article is organised as follows. After sketching out the main features of the government of Uganda's settlement system, it considers some of the issues arising with respect to the enjoyment of refugee rights, notably freedom of movement. Drawing on refugees' own analyses, it then examines reasons given by informants for opting in or out of the settlement system. Next, it questions the conventional dichotomy between the position of refugees living in and out of refugee settlements in the Ugandan context, asking how far the distinction holds up empirically. It then examines some of the constraints on refugee livelihood which appear to be in part or whole attributable to the structure and nature of the settlement system as currently constituted for refugees. It shows that refugee livelihoods face more rather than fewer challenges as their exile becomes protracted. Finally it asks what implications arise for any further SRS/ DAR style interventions in Uganda and elsewhere, before concluding.

The government of Uganda requires that on arrival refugees register with the government authorities, and live in formally organised refugee settlements in locations identified by the government. These tend to be in remote and marginal areas close to the international border, where access to markets can be problematic and where security has often been far from assured (see map below). The GoU's local settlement policy, which derives its legal basis from the Control of Alien Refugees Act (CARA) ${ }^{6}$ reflects its primary interest in questions of national security, as well as its emphasis on the eventual repatriation of refugees.

Established in agricultural settlements, refugees are allocated a plot (or plots) of land for residential and agricultural purposes. Movement out of any settlement is subsequently only officially allowed with a travel permit issued by the government's representative in the settlement (known as the 


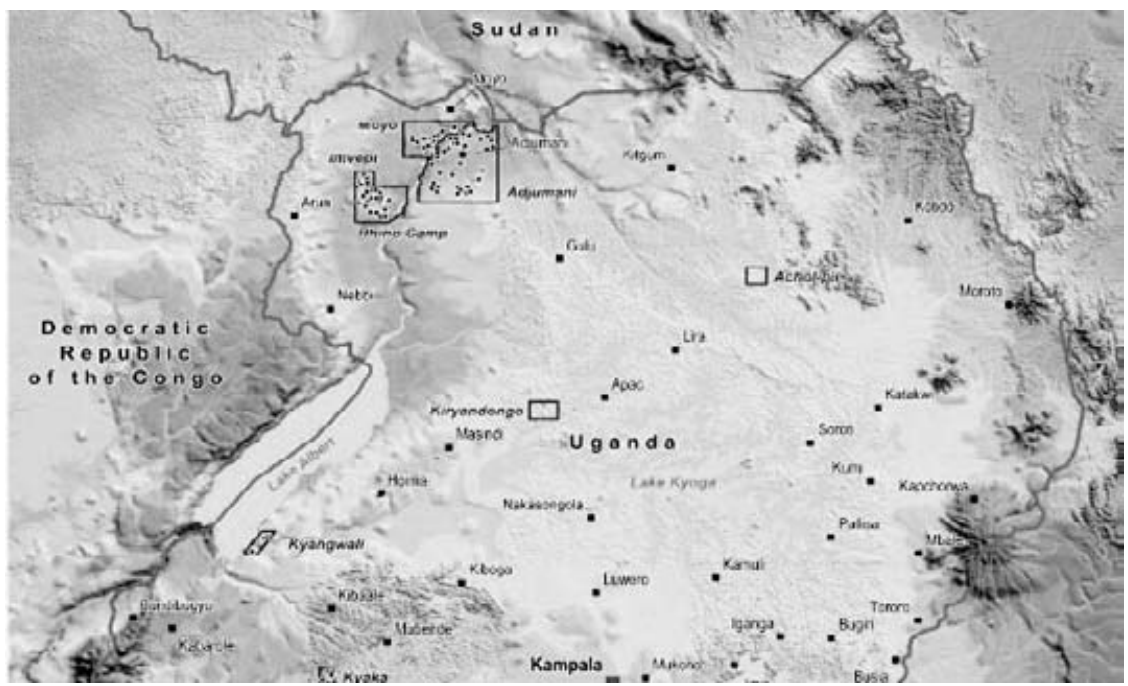

UGANDA

Localisation of refugee settlements

$\begin{array}{ll}\square & \text { Refugee area } \\ \text { - } & \text { Refugee Settlement } \\ \text { - } & \text { Refugee Transit Centre }\end{array}$

M A P I. Northern Ugandan refugee settlements. Source: adapted from UNHCR 2004.

settlement commandant). Refugees are not permitted to move permanently out of the settlement in which they are registered, nor are they usually allowed to transfer from one settlement to another. Settlements, including those in Arua District, are often remote, with poor access to markets and communication and transport systems. The Kiryandongo Settlement is an exception in this respect, being only a 3 -hour drive from the capital Kampala, and located only a few kilometres from a busy trading centre. ${ }^{7}$ Unlike in some other asylum countries in Africa, Ugandan settlements are generally not fenced, and where refugee villages have been established within them, small markets have also often opened, churches have been constructed, and one may also find beer or video halls, scrubby football grounds, or other markers of social and community life. The generosity of the people and government of Uganda in making 
agricultural land available for refugees has been rightly acclaimed by refugees and others.

In the early days of the refugee settlements in the early to mid-I99os, and as new arrivals were settled subsequently, registered residents were provided with a monthly food ration while they established their crops and waited for harvests. After a number of relatively successful agricultural seasons, rations were withdrawn for those deemed to be 'self-sufficient', and reduced for those moving towards this status. Decisions were made on a settlement by settlement basis after food assessment missions conducted by WFP/GoU/UNHCR. Some 'Extremely Vulnerable Individuals' (EVIs) continued to receive a full ration where necessary. Not everyone was always happy with decisions made.

In the late I99os the GoU and UNHCR took this policy one step further by introducing a 'self-reliance strategy' (SRS) for refugees. The programme was formally launched at UNHCR's ExCom 2004, and now fits into UNHCR's wider global strategy of Development Assistance to Refugees (DAR). Broadly, the SRS advocates 'self-reliance' for refugees, defined by UNHCR as a situation where refugees are enabled 'to gain the economic and social ability to meet essential needs on a sustainable and dignified basis' (UNHCR 2005: 3). It envisages a situation where services to refugees in agricultural settlements (previously provided by one of UNHCR's implementing partners) are integrated into district level government provision. On this basis, refugees access services in the same way as Ugandan nationals, rather than continuing to receive 'special treatment' via NGO provision. Few specifically income-generating interventions are included in the SRS, which appears to proceed largely on the assumption that refugees will subsist and even produce a surplus on the basis of agricultural activity, as well as small-scale local trade and petty businesses. The World Food Programme (200I: I0), which provides rations for refugees in Uganda, expresses specific concern about the fact that in the SRS 'no benchmarks are provided to measure recovery or the attainment of self-reliance', going on to note that 'a related weakness of the SRS is the lack of clarity about the conditions for selfreliance'.

\section{Freedom of movement}

Reflecting the wider discourse about refugee camps, views about the Ugandan settlement system are often polarised. On the one hand, humanitarian agencies including UNHCR tend to represent settlements as benign and supportive institutions, where people in need can take 
refuge and receive succour, thanks to the generosity of the host state and international donor community. Contrastingly, some analysts depict them as prison-like places where rights to freedom of movement - and related access to education, employment, meaningful family life and livelihoods - are denied refugees via this mechanism of control and containment (Hyndman 2000; Verdirame \& Harrell-Bond 2005). When refugees are being inadequately supported or enabled in settlements, there is evidently a greater incentive or tendency to favour the latter characterisation.

While the government asserts the generosity of its citizens in offering land for refugee settlement, critics point to the fact that the settlement system contravenes the government's international obligations with reference to the freedom of movement of refugees in their country of exile, enshrined in the UN 195 I Convention on the Status of Refugees (article 26), as well as other human rights instruments. ${ }^{8}$ Freedom of movement is a prerequisite for the enjoyment of a range of other rights. Its absence undermines refugees' economic and social rights, and the livelihoods of refugees in camps are thus severely limited in comparison with those of their peasant hosts.

In practice, it is evident that significant numbers of refugees in Uganda evade the settlement framework by failing to register their presence as refugees, or by illegally leaving the settlements after they have done so. The status of such 'self-settled' refugees in Uganda is uncertain. They are unrecognised as refugees by the GoU, nor are they recognised or supported by UNHCR. As 'aliens' rather than refugees, they occupy a precarious and ambiguous status, enjoying neither the rights of Ugandan citizens (unless they are able to acquire identity documents and 'pass' as nationals), nor the protection and limited material support of refugees in settlements. Nevertheless, they participate fully in all but political activities, and contribute significantly to the economies of the areas where they live (Kaiser et al. 2005; Okello 2005).

Refugees in Uganda are officially denied the freedom to decide where they prefer to settle, with all that this implies for their ability to make strategic livelihood and other choices. While their plight may be less dramatic than that of refugees in neighbouring Kenya, who are confined to enclosed camps in semi-arid and hostile environments with no access to agricultural land, it remains the case that refugees in settlements in Uganda do not enjoy their legal rights. One of the least comfortable aspects of the debate on refugee settlements in Uganda is that critics are continually invited to agree that the conditions in refugee settlements there are better than in some camps in other countries or, indeed, than 
IDP camps in Uganda itself. While this may in many cases be true, it does nothing to obviate the difficulties faced by Sudanese refugees in Ugandan settlements. The fact that the rights of some others are abused more than theirs, does not mean that their own rights are not also being undermined.

In addition, and contrary to international refugee law, the implementation of the settlement policy in Uganda has effectively redefined the category 'refugee', so that it has come to refer only to a person who is in receipt of assistance and living in a physical space defined by the government of Uganda. Individuals who have crossed an international border to seek protection, and who are defined as refugees on this basis under international law, ${ }^{9}$ are excluded from the benefits of the status in all practical respects in the Ugandan context. This policy is made financially and materially feasible by the UNHCR. Despite this concentration on settlements, after several years of existence, these still do not provide the conditions for economic survival, and refugees in them are consequently still heavily reliant on food aid. With settlements located in relatively remote and impoverished areas, employment and other income-generating opportunities for refugees are largely absent. Although services for refugees are ostensibly provided in settlements, in practice delivery is very unreliable and refugees are left facing a shortfall which they cannot remedy (Kaiser et al. 2005).

\section{Reasons to stay, reasons to go}

Conversations with Sudanese refugees in Arua typically elicited a number of unprovoked complaints about life in the settlements, their conditions and services provided there. Notwithstanding these complaints which are discussed in more detail below, in Rhino Camp and Imvepi settlements significant numbers of refugees reported that they had opted to remain in the settlements because of the food, water and social services which are provided to them there. Such support is particularly crucial for those with special needs, such as unaccompanied minors, who may have no other prospect of acquiring food. No material assistance of any kind is offered to refugees who do not register with the government, and do not go to settlements.

The availability of agricultural land in the settlements is also a decisive factor for many people, and the opportunity to grow some crops is undoubtedly welcomed by the many farmers within the population. Given that only a minority of refugees in Imvepi and Rhino Camp Settlements are currently receiving a full food ration, the accessibility of 
agricultural land is crucial (OPM Clerk Imvepi 2004 int.). In Imvepi, 'old caseload' refugees who arrived before 200 I receive a half ration, while those arriving later still receive a full ration. In Rhino Camp, most people were in 2004 receiving $40 \%$ or $50 \%$ rations. Almost all the refugees encountered engage in some form of agricultural activity. As food rations are reduced or phased out under the SRS, the quantity and quality of land available becomes increasingly important. For many refugees, including a community development worker in Imvepi, the fact that they have no way of accessing land outside the settlement means that they have no alternative but to stay on the land they have been given; 'the government says there is no other place to be given for us ... it is government policy, what can we do?' (female community facilitator, Imvepi 2004 int.)

Some refugees also indicated that at the time of the research, they felt more physically secure living in a settlement than they would outside one. This appeared to be partly because they did not know people or have contacts elsewhere in Uganda, and partly because as one man put it, in the settlements now, 'life is safe' (male refugee, Imvepi 2004 int.). The unpredictability of the security situation in northern Uganda means that of all the factors, this must be the most variable.

Attitudes towards living in or outside settlements are not uniform, and are expressed both positively and negatively. On the one hand, there is some suspicion about the risks of life outside the settlements; one refugee man asserted that most people stay in the settlements because of their health and education services, adding 'the conditions they are facing there [i.e. outside the settlements] are worse than here; security is a problem; when they fail to produce crops, it is a problem' (male refugee, Odubu Centre, Rhino Camp 2004 int.). In this representation, the settlement exists as a safety net, a protective environment, and in at least one refugee meeting there was strong agreement that living in a settlement is not in itself a problem, only its remoteness and distance from markets. On the other hand, some residents of Rhino Camp also felt that it is the hardships of life in the settlements, rather than the inherent attractions of life outside them, that force people to go; 'those people from [i.e. now in] the urban areas just went from here because of the problems here' (RWC III chairman, Rhino Camp 2004 int.).

What reasons were offered in explanation by refugees living outside settlements? Paradoxically, the main points raised by respondents referred to the same preoccupations and priorities as those of settlement refugees. Self-settled refugees also cited insecurity (this time in the settlements), the availability of better quality land and economic opportunities outside, 
and even access to superior education and health services, as reasons for leaving or staying away from settlements. One refugee man now living near a village in the Sudan/Uganda border area in West Nile, described his fear on being caught up in an LRA attack in the Ikafe settlement, and his reluctance to expose himself to similar insecurity by returning to a settlement. 'They welcomed me [here], no problem ... I faced it rough in the camp [i.e. because of insecurity], so I can't decide to go back there unless it becomes bad [insecure] here' (male Sudanese self-settled refugee, Koboko County 2004 int.).

Refugees with business interests or the wherewithal to get involved in trade, professional activities or other non-agricultural activities, asserted their desire to remain in urban settings to pursue these objectives. One man described how living near the border facilitated his church work in both Uganda and Sudan. He explained that he paid graduated tax and that this eased his movement between the borders (male self-settled refugee, Ombachi, Koboko 2004 int.). ${ }^{\mathbf{1 0}}$ Another elderly woman, living in Arua town with a large number of young dependants, explained that she could not contemplate taking them to a settlement as this would diminish their educational opportunities. As she acknowledged, it would have been impossible for her to remain in town without the monthly remittances received from a daughter in the USA, whose contributions paid for the rental of a house and food for the family.

The contribution made to the local economy by refugees is acknowledged by self-settled refugees and their Ugandan hosts, in the rural and urban areas. Similarly, while numerous cases of local conflict over land, resources and behaviour were reported between individual refugees and hosts in settlement contexts, there was no suggestion of any systematic or generalised hostility towards refugees on the part of the national community in these areas.

Finally, it was notable that when questioned about their reasons for remaining in or leaving settlements, few refugees in Arua or in Masindi raised the question of the legal requirement that they should stay there. This was partly because it is clearly fairly easy to subvert the requirement in the presence of enabling conditions, and partly because the challenge to their right to move was in many cases evidently not conceptualised explicitly as an abuse. It is, however, very important to note that almost the exact opposite was reportedly the case when related research was carried out by the Refugee Law Project in Moyo District (Okello et al. 2005), and this difference has not yet been fully explained. Nevertheless, it is important that, as will become clear below, problems associated with the limitations of settlement life or refugee life were constructed as economic 
problems rather than rights issues by many of the refugees consulted in Arua.

SETTLEMENT VERSUS SELF-SETTLEM EN T: HOW SECURE

ARE THE CATEGORIES?

Discussions of responses to refugees in the developing world often assume a clear opposition between the experience of refugees living in camps and settlements, and those living 'self-settled', often outside the formal economy of refugee registration and assistance. Findings in Uganda suggest that the situation is rather more complicated than this, with refugees occupying overlapping and fluid categories which change over time. One indicator is the fact that refugees both in settlements and out of them prioritise the same criteria when deciding whether to stay in or leave settlements, suggesting that they are reaching different decisions for reasons that refer to individual differences between them, rather than to objective conditions. Second, refugees' accounts indicate a much less static picture of the distribution of refugees in and out of settlements than the official account suggests (i.e. legitimate refugees in settlements vs. undocumented 'aliens' outside - see Table I). Rather, a picture is presented of a constantly changing context, with probably a minority of individuals moving in and out of settlements as their needs change, while others live outside settlements but maintain strong and important connections with people or institutions in settlements, or vice versa.

The tentative findings of a small, snowball sample of 'self-settled' refugees living in Arua and Koboko towns, as well as in what were then the rural areas of Koboko sub-county (now Koboko District), revealed that a significant number of self-settled refugees had previously lived in settlements, but had fled from them during times of insecurity and not returned. They had, in an important sense, never 'decided' to leave the settlements, but had fled in the midst of a crisis, and not gone back (self-settled Sudanese refugee family, Koboko County 2004 int.). One self-settled refugee woman now living in Awindiri village, for example, left the Ikafe settlement after rebels attacked it. She was able to buy a piece of land in Awindiri for UShs 400,000 (c. E, I3o), and now survives by doing casual labour there (female self-settled refugee, Awindiri village 2004 int.). Confusion about the rules reigns in many quarters, among refugees, local government officials and Ugandan citizens alike. It was clear that many refugees did not know what they were and were not entitled to in terms of protection and assistance. One refugee family living in Koboko town claimed, paradoxically, to have been refused re-entry to a settlement after 
TABLE I

Refugees in and out of settlements - in principle and practice

Settlement Refugees

Legal - prima facie 'refugee' status

Protection and recognition by UNHCR

Receives assistance in form of services and in some cases, food rations (assumes involvement of the international donor community)

Government claims refugees enjoy freedom of movement. But freedom to move relies on settlement commandant issued travel documents. In practice, a range of documents can be used including student IDs, SPLA documents, Ugandan graduated tax card.

Included in the self-reliance strategy

Ostensibly, security

Little access to employment/income-generating activity. Markets very limited, transport costs prohibitive, employed refugees in settlements in receipt of low 'incentives' rather than salary.

Destination for those without a more attractive alternative, the default.
Non Settlement Refugees/'Aliens'

Undocumented 'alien'

No protection or recognition by UNHCR

No direct or indirect assistance. No assistance to Ugandan self-settled refugee hosting communities.

Freedom of movement, dependent on one of a number of forms of documentation including student IDs, SPLA documents, Ugandan graduated tax card, letter from LC I (local councillor, elected official). Vulnerability to harassment or exploitation if paperwork not accepted.

Explicitly excluded from the self-reliance strategy Uncertainty with, arguably, autonomy.

Access to employment/income-generating activity (Highly variable - dependent on location, education, skills, contacts).

In general only available to those with external resources of one kind or another. i.e. requires 'capital'; financial, ethnic, social, political or other (see Van Hear 2004).

fleeing from it after an episode of insecurity, on the grounds that they were now 'town refugees' - a meaningless category in legal terms.

Even those who do make a positive decision to leave settlements may hold multiple identities or statuses. A very large number of settlement refugees are involved in day wage labour, and this takes most of them out into the environs of the settlement on a regular basis. As is entirely normal in many rural African contexts, some people - mainly but not exclusively young men - go one step further and leave the settlements for a few weeks or a month at a time to get casual work in a more distant rural or urban environment, leaving their families in the settlement (refugee elder, Odubu Centre, Rhino Camp 2004 int.). These individuals retain their settlement registration, and family members may also continue to receive food rations on their behalf in their absence. ${ }^{11}$

A significant number of people are not fixed in either a settlement or a non-settlement context, but somehow bridge the gap between the two, deriving advantages from each. In some cases, this means that people once registered in settlements continue to receive a food ration there, only to 
collect it and bring it to where they actually live in town (male self-settled refugee, Imvepi 2004 int.). In practice, this is easiest to manage if the family is divided between the settlement and town. Others have never lived in a settlement but are nevertheless registered there, and in some cases therefore receive food rations too (young male self-settled refugee, Ombachi 2004 int.). People's needs change over time, and one woman in Arua, quoted above as saying that she needed to stay there so that her dependants could attend better quality schools, did not rule out the possibility that she might return to a settlement once the children had completed their schooling. There, she would be able to live more cheaply, since she would not have to pay rent for accommodation and food could be got less expensively too. Refugees may thus be well aware of the relative advantages and disadvantages of living in different locations, and deploy different strategies at different times to meet their specific and changing needs as far as they can. In almost all cases, movement in and out of settlements was described by refugees as being motivated primarily by the need to secure a reliable livelihood. It was overwhelmingly the case that the settlements were described as poor places to pursue this goal by those who had left them, as well as by many people still living in them.

This being the case, it should come as no surprise that those individuals or families who had left the settlements usually reported having some external support that allowed them to do so. In a few cases, refugees were able to bring assets or resources with them from Sudan, and thus had some capital with which to work. In other cases, they managed to secure paid employment (which can itself require a significant investment of money), or identified a patron who could support their plans. The opening of a new Western Union office in Koboko indicates the arrival of remittances locally, and many refugees reported receiving some support from friends of families who had contrived to relocate to other countries in the region, or to the developed world. ${ }^{12}$ There is a strong perception within settlements that people who have been able to leave are those who have access to contacts or resources above and beyond the minimal support provided to registered refugees, or who via such networks were able to access employment or training. 'Those who could not afford, those are the ones in the settlement' (RWC III chairman, Rhino Camp 2004 int.); and 'those who don't have people in America, we are here' (member of a refugee cultural group, Rhino Camp 2004 int.). This view was frequently articulated (male refugee, Point E, Imvepi 2004 int.; group discussion, Odubu Centre, Rhino Camp 2004). According to this characterisation, bare survival is possible in settlements, but any meaningful developmental activity requires additional support and relocation away from them. 
Illegality was again seldom articulated as a reason not to travel or move outside settlements, for those who had the resources or contacts to do so. These factors are likely to be linked, in that better-educated or connected individuals are more likely to be familiar with strategies that will keep them out of trouble, even though they are breaking the rules, than are illiterate farmers who are much more nervous about falling foul of the bureaucracy of the host state. A minority of cosmopolitan refugees laugh at the idea that they are to be controlled by petty rules about movement, when they have an important appointment or other business to attend to (group discussion, Kiryandongo 2004). ${ }^{13}$

\section{Constraints on refugee livelihoods in settlements}

This section examines some of the constraints on refugee livelihood which appear to be in part or whole attributable to the disadvantages of the settlement system as currently constituted for refugees. It suggests that refugee livelihoods face more rather than fewer challenges as their exile becomes protracted.

The findings of the research suggest that most refugees who live in settlements do so because they have no option but to rely on the minimal assistance which is provided to them there, even though conditions in settlements are far from optimal. Refugees complain that the conditions for self reliance do not exist in Arua's settlements, and that they still desperately need support from humanitarian actors. Many argue that they remain food insecure, and that they are in no position to cover educational expenses (especially paying school fees for secondary students) and health fees, when these services are unavailable freely in the settlements. To some extent these complaints are predictable and familiar to anyone with experience in a refugee setting. What is shocking is how little government officials, and even staff of UNHCR and its implementing agencies seem to aspire to for the refugees under their care. The willingness to ignore the gap which patently exists between what is required to support a decent standard of living in the settlements, and what is provided or accessible to refugees, is very great indeed for some of the following reasons.

Investigation into the availability and use of land in the settlements found that for many refugees, the agricultural land allocated to them was either too little or too poor in quality to allow them to achieve selfsufficiency. ${ }^{14}$ Environmental problems, soil exhaustion and increases in family size were represented as some of the most important reasons for its inadequacy. ${ }^{15}$ In Rhino Camp, such complaints as these expressed by an older refugee man were heard repeatedly: 'the problem is that the land is 
sandy, and not fertile ... Sometimes there is long drought, destroying all the crops. Sometimes when it rains, the agric land is flooded ... It is not only affecting the refugees, it is also affecting the nationals. Because of that threat of the weather, poor soil, the refugees here find it very difficult to get enough food for household consumption'(advisor to the RWC III, Odubu Centre, Rhino Camp 2004 group disc.).

One young man, a father of five, complained that not only was the soil of poor quality, but that his family size had increased from three to seven since he was allocated the plot, and that it was now too small for them to subsist on (male refugee, Ariwa V, Rhino Camp 2004 int.). The fact that settlement plots had no built-in capacity to deal with family reproduction or increases was noted as problematic by many interviewees, including a young woman in Rhino Camp (young female refugee, Odubu II, Rhino Camp 2004 int.; young male refugee, Tika III, Rhino Camp 2004 int.). This particular problem points to the difficulties faced by refugees as a consequence of their long exile in Uganda. Not only do they face a reduction in inputs to the settlement under the SRS, but their land holdings also decrease in value as time goes by. A plot of land considered adequate in size for a small family now has to support one twice the size. Meanwhile, the lack of sufficient land to practice shifting cultivation means that the soil inevitably produces fewer crops than it did when first allocated. ${ }^{16}$

While some refugees can access additional land from hosts (usually after a payment in cash or kind has been made), they have no security of tenure or use over such holdings. Numerous cases of refugees being forced off land they had begun cultivating were reported. In an important minority of cases, land officially allocated to refugees is even reported to have been 'grabbed' back by nationals, with little evidence that such incidents have been systematically followed up by the authorities.

Non-agricultural income-generating opportunities in the settlement are very rare and hold their own risks. Describing the pitfalls associated with a loan scheme, a church leader explained, 'Our problem here is poverty and hunger. We normally start business but after two to three months the business is finished because the same money which is put in the business is also used for feeding' (male refugee pastor, Tika II, Rhino Camp 2004 int.). Casual work or day labour outside the settlements is by far the most commonly cited way of raising cash, according to refugees in all the settlements covered here. Despite the risks of exploitation or abuse by Ugandan employers, refugees routinely represented this form of income generation as their lifeline. It should be noted that refugees are open to abuse largely because of their status as refugees, either because they have 
left settlements illegally to work and have no recourse if they are left unpaid or underpaid, or because their cases are not strongly followed up by government officials if they try to assert their rights.

Even professional people complain that they miss what few employment opportunities might be open to them, because they do not have the resources needed to pursue them. One frustrated refugee health professional described how he was unable to raise enough money to travel to apply for jobs for which he was well qualified and experienced. 'I heard of a job in Sudan, then another in Koboko - I failed to go and apply. Those who had money were the ones taken - they stay in the towns' (secretary to the RWC III, Imvepi 2004 int.). Similar constraints exist for those attempting to carry out small-scale trading or other business activity. Transport between the settlements and local markets (e.g. in Arua and Koboko) is sporadic and expensive. In a document which largely enthusiastically approves the SRS in Uganda, even UNHCR's consultant acknowledges with considerable understatement that 'livelihoods can be further hindered by placing refugees in remote and unfamiliar environments ... more success could be booked if refugees were to have access to markets and employment opportunities' (De Vriese 2006: 3I). Refugees are prevented from leaving the settlements or engaging on a commercial basis outside them, not only by the formal restrictions on freedom of movement, but also by lack of resources and the limitations on economic development for individuals in the settlement.

Overall, refugees generally remain gloomy about their prospects of reaching self reliance in the Ugandan settlements, but reject the notion that this results from their passivity or dependency; 'We grew through self reliance - in Sudan we were not living from hand-outs, just here ... Self reliance is not something new ... When 'self reliance' [SRS] came in, we found a lot of problems' (RWC III chairman, Rhino Camp 2004 int.). In this view, the handover of services from UNHCR and its implementing partners to the district authorities represents a mechanism for the reduction of services for refugees and a cost saving strategy. The SRS is commonly perceived as designed to support the development of Uganda's refugee hosting areas, rather than the refugees themselves; 'Yes, we have agreed to be under SRS since I999, but what about our development?' (secretary to the RWC III, Imvepi 2004 int.).

There are significant differences between the response strategies available to settlement refugees in Arua and to their hosts. While policy-makers often assert that the position of refugees in Uganda does not differ greatly from that of their rural Ugandan hosts, Rhino Camp refugees routinely explained differences in terms of indigenous farmers' dispersed land 
holdings, only some of which fall within the band which constitutes the Rhino Camp area. For this reason, Ugandan farmers are sometimes able to diversify their agricultural activity, and spread risk by mixing cash and subsistence farming in different climatic zones. In this case, for example, Ugandan farmers could sometimes grow tobacco for sale in areas further away from the settlement, while such a crop would be impossible to grow within Rhino Camp Settlement proper. Like the very poorest hosts, restricted to a single plot of land in the settlement, refugees are unable to do this.

Access to refugee related employment is one clear way in which the arrival of refugees in the sub-counties has benefited nationals who live in them. They also have other advantages: 'The nationals have cattle and goats and enough land for grazing. They have access to businesses, and to loans' (advisor to the RWC III, Odubu Centre, Rhino Camp 2004 group disc.). 'They talked of comparing us with the nationals - but the nationals have animals there - we don't have. If they want us to join SRS they should give us loans so we can get other things as well' (male refugee teacher, Imvepi SHSS 2004 int.). 'The national is a landowner' (advisor to the RWC III, Odubu Centre, Rhino Camp 2004 group disc.), emphasised one refugee leader, distinguishing between having the use of land and actually owning it, and the freedom of choice that this implies. There are also specific economic activities which are not open to refugees. In Rhino Camp, for example, refugees were not entitled to catch fish in the Nile; 'The nationals are better off because they can get money from the river' (headmaster, Tika Primary School, Rhino Camp 2004 int.). Indeed, the River Nile is known locally as 'the World Bank'.

Why do more refugees not leave the settlements if life there is so hard? As described above, leaving the settlement usually requires some form of capital, and this is not available to all refugees. One common and particular source of support remains to be identified, and this is the help which is sometimes available to refugees from co-ethnic nationals. The Ugandan Koboko border area is largely occupied by Kakwa people who also live on the Sudanese side. For refugee members of this ethnic group in particular, 'ethnic capital' can be deployed and can assist in the granting of land and other support under certain circumstances. A Ugandan Kakwa, previously a refugee in Sudan, described how his community is now hosting the people who formerly hosted them. 'We call them as our brothers, we have a common historical origin and are the same people, it is only the border which divides us ... the children play together, use the same language, go to the same schools, there is no point in saying that this [person] is from a different country-no!' He stated that refugees are 
given land without payment: 'they first go to the camps and then come [here] from there ... on finding that the food given is not enough, they resort to coming here to get land for cultivation' (Ugandan parish chief, Koboko 2004 int.). Non-Kakwa refugees generally do not come asking for land. He noted that his community has not benefited from any assistance or development programmes due to the presence of the refugees. Since their presence in the border villages is not formally registered, this is not surprising.

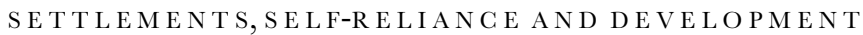

While the length of time that Sudanese refugees have spent in Uganda is represented as one reason that they should 'by now' have become selfreliant, the weaknesses of the settlement system and the SRS have in fact become more obvious over time. Refugees insist that their predicament has worsened over the years for the reasons mentioned here; insecurity, premature withdrawal of food rations, soil exhaustion, family increase without additional resources, and reduction in the quantity and quality of social services available in the settlements, as UNHCR and its implementing partners hand over to the already stretched district authorities. Just as care and maintenance programmes could last for many years without improving the conditions of life for refugees, so the agricultural settlement system has allowed for the bare maintenance of many refugees, rather than their development in any significant way. Observations and research in the settlements signally do not lead to confidence that refugees are being enabled 'to gain the economic and social ability to meet essential needs on a sustainable and dignified basis' (UNHCR 2005: 3).

Several issues arise from the restriction of refugees to settlements, and from the fact that only refugees in settlements receive assistance from UNHCR and its partners. Service provision has become inextricably linked to the idea of settlements in policy debates and in the Ugandan case, although there is no necessary reason for this to be the case. The insistence on refugee settlements ensures the creation of a category of people who are excluded altogether from their assumed benefits. Under the settlement system, refugees living outside settlements, as well as their generous Ugandan hosts, are unconsidered in discussions concerning the sharing of resources, while such refugees are left entirely without legal protection. Meanwhile, refugees who do take control of their predicament and exploit complementary livelihood opportunities, including receipt of food rations, agricultural production and additional forms of 
extra-settlement activity, place themselves firmly outside the law - however 'developmental' their intentions.

It is not simply a neutral fact that refugees tend to be impoverished and that, needing assistance, they stay in settlements where this is provided for them. Rather, the political and institutional response to refugees in Uganda constructs a situation where refugees' own capacities, potential, and comparative advantages may effectively be stripped away from them, and where serviced settlements are represented as the answer to their problems. The concern is that their 'problem' has been very narrowly defined, and the settlement solution is an insufficiently subtle mechanism to meet the diverse and wide-ranging needs of populations differentiated by experience, aspiration and capacity.

Meanwhile, refugee expectations have probably risen since the early days of their exile, when survival and regrouping were the main aims, and may now reasonably be higher than they might have been had these groups never left Sudan. Exposed to a more developed exile country, and having benefited from UNHCR's health and education services, refugee youths compare their opportunities with those enjoyed by Ugandan youths, not with the hardships borne by stayees in the insecure and impoverished home area. Many therefore aspire to complete secondary education or benefit from vocational training, expect to be able to access treatment when sick, and so on. Refugees perceive that the extent to which these expectations are being met has diminished in recent years and with the introduction of the SRS.

There is evidently variation between settlements and experiences of them. It may therefore be helpful at this point to briefly consider the case of Kiryandongo, which is frequently represented as a model settlement as far at the SRS is concerned (Kaiser 2005). Many residents of Kiryandongo reject claims that they are now comfortably self-reliant, pointing to their many unmet educational, vocational and livelihood needs. Nevertheless, some of them have certainly found it easier to regularly meet basic needs than their peers in Imvepi and Rhino Camp. Why should this be the case, and can this example teach us anything about the conditions required to support a degree of self-reliance? The most obvious and probably the most important variables refer to structural conditions over which refugees have little or no control. First, it is widely acknowledged that, with some important exceptions, soil fertility in Kiryandongo is better than that in the settlement areas of Arua district. This may be beginning to change, as farmers in Kiryandongo complained bitterly in 2006 about their dramatically reduced crop yield, which they explained in terms of the increasing exhaustion of the soil and the failure of the rains in late 2005 . 
Second, due to its location south of the Victoria Nile, Kiryandongo has never experienced the insecurity that has undermined economic activity of refugees in Arua over a period of years, and which has resulted in the death, injury or displacement of many of them. Finally, as already noted, Kiryandongo benefits from its location near a main road and trading centre, to whose fortunes refugees have heavily contributed. If, as seems probable, these structural factors are the critical variables for relative success, there may be little that refugees in less favoured areas can do to emulate the relative success of some of the Kiryandongo farmers.

\section{Self-reliance strategy/development assistance for refugees}

What are the implications of all of this bad news for the 'SRS' and UNHCR's new, global DAR strategy? A series of unresolved contradictions remain. First, although the UNHCR DAR strategy considers the enjoyment of refugee rights a pre-requisite if developmental approaches to refugee assistance are to be successful, the SRS itself undermines these. ${ }^{17}$ Second, despite significant efforts to integrate services to refugees into district structures, the SRS explicitly excludes any meaningful socioeconomic integration of the refugee population into the host society. With refugees maintained apart from host communities, the interconnections, relationships and networks between them on which successful development programming could be based, are absent. With refugees restricted to agricultural activity on exhausted and insufficient land holdings, and excluded from meaningful alternative income-generating activity, the question of whether scaled-down support in settlements is provided by UNHCR or GoU may not be of critical importance. Third, despite aspiring to the development of both refugees and hosts - necessarily a project that requires engagement with a dynamic process of social and economic activity - the SRS refers to an almost entirely static picture of the refugee population and their efforts, failing to recognise that conditions, capacities and objectives change over time.

Finally, many of the 'coping' or 'survival' strategies employed by refugees outside settlements, which demonstrate initiative, entrepreneurial skills and innovation, remain unlawful in the context of the settlement system. If refugees were free to live outside settlements, and were offered appropriate supportive assistance there, their capacity for developmental progress might be expected to increase. It must be recognised that not all refugees have the same developmental capacities, and that meeting the needs of those with particular disadvantages would have to remain a priority. Nevertheless, there are grounds for exploring further the 
proposition that in relation to refugee livelihoods and developmental approaches to refugee assistance, such (currently illegal) refugee coping strategies may be the most fertile area to explore if we are serious about facilitating the development of refugees and their hosts.

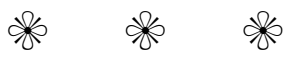

The GoU's failure to recognise as refugees those people who satisfy the legal criteria laid out in the 195I UN Refugee Convention and the 1969 OAU Convention, whether or not they live in settlements, should be remedied immediately. These people should be provided with the international protection of UNHCR. To deny them their rightful status in an attempt to persuade them into settlements is neither just nor generous.

The SRS evidently seeks to integrate refugee services into district service provision and from the point of view of the elimination of wasteful parallel structures of refugee assistance, this makes good sense. However, the expectation that refugees will achieve and sustain 'self-reliance', in the absence of any substantial interventions designed to address the main obstacles to this goal, is less obviously well founded. The policy dialogue around the SRS in settlements usually fails to discuss such obstacles. How can refugees produce a surplus when their plot is too small, the soil exhausted, or when the rains fail to come, as in 2005? How can they effectively market any surplus they do make, when settlements are remote and access to markets poor? How can refugees gain employment, when many or most of them are too poor to travel to make an application or attend an interview? How then can refugees in settlements be expected to raise cash with which to pay for health and educational expenses, when these are inadequately covered by district provision?

There is little evidence that these problems have been acknowledged by an assistance regime that appears to prefer to deny their existence, so that the limited administrative and political successes of the integration of services can be lauded as a success story in its own right. The fact that those refugees with access to any form of external capital tend to leave them, is not a promising indicator of the development capacity of settlements. The fact that these people are then no longer counted as refugees hints that developmental success by refugees is welcome not on any terms, but only within the parameters set by the settlement system. Since refugees who remain outside settlements are unrecognised and unsupported, it is very difficult to compare their situation with that of refugees living in settlements; but the fact that some have opted for an independent life and are making their own way even in the 
disadvantageous context of illegality and risk, demonstrates that some success has been achieved.

Refugees in settlements strongly feel that they are positively excluded from developmental activity in Uganda. While UNHGR's desire to move away from endless care and maintenance provision in situations of protracted exile must be good for all stakeholders, this case suggests that the rather limited attempts made by the Ugandan SRS to promote refugee development without removing the principal obstacles to it, have had very limited success. Future initiatives will need to be more imaginative about finding ways to overcome the economic, social and political limitations inherent in settlements. Conceivably, UNHCR may itself take the courage one day, to move right away from its reliance on settlements, and play a much stronger protection and assistance role by encouraging host states such as Uganda to reconsider their insistence on the incarceration of refugees in what might be labelled anti-developmental settlements.

\section{NOTES}

I. Bakewell 2000, Hansen I982, Okello 2005 and Van Damme i995 are among the relatively few exceptions.

2. Refugees from Rwanda and DRC are also found in the south and south west of Uganda. This article does not consider their situation, since although they are also required to live in settlements, the SRS has not yet been applied in relation to them.

3. The research in Arua was carried out with a team of researchers from the Refugee Law Project, Kampala, as part of a wider study on the settlement system in Uganda. The results of this study are available as RLP Working Paper No. I4 (Kaiser, Hovil \& Lomo 2005) at http://www.refugeelawproject.org/publications.htm. The report also includes further details on research methods and modalities.

4. More information on livelihoods in the Kiryandongo settlement can be found in Kaiser 2006.

5. In 2004 figures were; Arua; Imvepi Settlement I9,092 refugees, Rhino Camp 26, I73, and Madi Okollo Settlement 6,928. Figures from UNOCHA, Humanitarian Update, Kampala, June 2004.

6. Section 8 of the CARA specifically requires refugees to live in settlements. The CARA may soon be replaced by the 'Refugee Bill, 2003', which grants refugees freedom of movement, but also notes that freedom of movement 'is subject to reasonable restrictions specified in the laws of Uganda, or directions issued by the Commissioner' (Section 30).

7. This trading centre, Bweyale in Kibanda County, has boomed since the arrival of the refugees and a substantial IDP population from the early ig9os. Both the refugees and IDPs travelled south from LRA affected areas where each had been attacked previously (Kaiser 2000).

8. Notably the 1948 Universal Declaration of Human Rights. See also Verdirame \& Harrell-Bond 2005 .

9. A refugee is someone who 'owing to well-founded fear of being persecuted for reasons of race, religion, nationality, membership of a particular social group or political opinion, is outside the country of his nationality and is unable or, owing to such fear, is unwilling to avail himself of the protection of that country', I95 I UN Convention Relating to the Status of Refugees.

Io. Graduated tax is now abolished but payment previously generated a receipt which was used as an ID document by many.

I I. Whether any or all of these refugees apply for a government permit before travelling varies from case to case. It should be noted that in Rhino Camp, for example, the office at which an application needs to be made is a full day's walk from some of the refugee villages. As one man put it, 'this asking for permission is a problem ... it is $24 \mathrm{kms}$ from Tika to Yoro Base so unless it is a special reason [e.g.] a funeral in Koboko - it's difficult' (headmaster, Tika Primary School, Rhino Camp 2004 int.). 
I2. The question of refugees' receipt of remittances is crucial, but unfortunately, no quantitative data currently exists on the Ugandan experience. This is an obvious gap in our empirical understanding and undoubtedly results partly from the difficulty in carrying out research on such a sensitive topic.

I3. Whether or not refugees can move out of settlements easily without a government travel permit depends on a number of factors, including the attitude of the settlement commandant, the political conditions which pertain, and the kind of journey undertaken. Travel permits set temporal and geographical limits to journeys, and refugees apprehended by the security services without such a document are liable to be jailed.

I4. Allocations were made on the basis of family size, with 0.3 hectares (Rhino Camp) and 0.2 hectares (Imvepi) being allocated per person on arrival.

I5. See also IRD 2003, UNHCR 2003 and UNHCR 2004, which cite among other reasons, unfavourable climatic conditions, small plot size and soil exhaustion for failure to reach self-sufficiency in $40 \%$ of cases in northern Uganda.

I6. In 2006, after the widespread failure of the rains in Uganda at the end of 2005, UNHCR was obliged due to a funding crisis to abandon both its environmental and agricultural extension work in Kiryandongo and elsewhere.

17. UNHCR (2003: 7) acknowledges the 'limitation due to the lack of a legal framework that entitles refugees to rights of various kinds' in the context of the SRS, and asserts the need for a clear 'legal fabric' (ibid.), pending the new refugee legislation.

\section{R E F E R E N C E S}

Bakewell, O. 2000. 'Repatriation and self-settled refugees in Zambia: bringing solutions to the wrong problems', Journal of Refugee Studies 13, 4: 356-73.

Black, R. 1998. 'Putting refugees in camps', Forced Migration Review 2: 4-7.

Crisp, J. 2003. 'No solutions in sight: the problem of protracted refugee situations in Africa', New Issues in Refugee Research No. 75, UNHCR, Geneva.

Crisp, J. \& K. Jacobsen. I998. 'Refugee camps reconsidered', Forced Migration Review 3: 27-30.

De Vriese, M. 2006. Refugee Livelihoods: a review of the evidence. UNHCR Evaluation Reports EPAU 2006/04.

Hansen, A. 1982. 'Self-settled rural refugees in Africa: the case of Angolans in Zambian villages', in A. Hansen \& A. Oliver-Smith, eds. Involuntary Migration and Resettlement: the problem and response of dislocated people. Boulder, CO: Westview, I3-37.

Harrell-Bond, B. E. I986. Imposing Aid: emergency assistance to refugees. Oxford University Press.

Hyndman, J. 2000. Managing Displacement: refugees and the politics of humanitarianism. Minneapolis, MN: University of Minnesota Press.

Institut de recherche pour le développement (IRD). 2003. Geographical Information System, Environment and Camp Planning in Refugee Hosting Areas: approach, methods and application in Uganda. Available at http:// www.bondy.ird.fr/carto/refugies/index.html

Jacobsen, K. 200I. 'The forgotten solution: local integration for refugees in developing countries', New Issues in Refugee Research No. 45, UNHCR, Geneva.

Johnson, D. 2003. The Root Causes of Sudan's Civil Wars. Oxford: James Currey.

Kaiser, T. 2000. 'Experience \& consequences of insecurity in a refugee populated area in northern Uganda', Refugee Survey Quarterly 19, I: 38-53.

Kaiser, T. 2005. 'Participating in development? Refugee protection, politics and developmental approaches to refugee management in Uganda', Third World Quarterly 26, 2: 35 I-67.

Kaiser, T. forthcoming 2006. "Moving up and down looking for money": making a living in a Ugandan refugee camp', in J. Staples, ed. Livelihoods at the Margins: surviving the city. London: UCL Press.

Kaiser, T., L. Hovil \& Z. Lomo. 2005. 'We Are All Stranded Here Together': the local settlement system, freedom of movement, and livelihood opportunities in Arua and Moyo Districts, Refugee Law Project, Working Paper No. I4.

Marfleet, P. 2006. Refugees in a Global Era. Basingstoke: Palgrave Macmillan.

Office of the Prime Minister \& UNHCR Uganda. 1999. Strategy Paper: self-reliance for refugee hosting areas in Moyo, Arua and Adjumani Districts, 1999-2005. Kampala: UNHCR \& OPM.

Okello, M. C., N. Gottschalk \& K. Ridderbos. 2005. 'There Are No Refugees in this Area': self-settled refugees in Koboko, Refugee Law Project, Working Paper No. I8. 
Smith, M. 2004. 'Warehousing refugees: a denial of rights, a waste of humanity', in World Refugee Survey 2004. Washington, DC: US Committee for Refugees.

UNHCR. 2003. 'Development assistance to refugees (DAR) for Uganda Self Reliance Strategy: way forward', Report on the Mission to Uganda, I4th to 2oth of September 2003, RLSS/DOS Mission Report o3/ir.

UNHCR. 2004. Self-Reliance Strategy (1999-2003) for Refugee Hosting Areas in Moyo, Arua and Adjumani Districts, Uganda: report of the mid-term review. RLSS Mission Report 2004/o3.

UNHCR. 2005. Local Integration and Self Reliance. Executive Committee of the High Commissioner's Programme Standing Committee, EC/55/SC/CRP. 5 UNHCR, Geneva.

Van Damme, W. I995. 'Do refugees belong in camps? Experiences from Goma and Guinea', The Lancet 346, 8971 : 360-2.

Van Hear, N. 2004. 'I went as far as my money would take me': conflict, forced migration and class. Oxford: COMPAS Working Paper No. 6.

Verdirame, G. \& B. E. Harrell-Bond. 2005. Rights in Exile: Fanus-faced humanitarianism. New York: Berghahn Books.

World Food Programme (WFP). 200I. Summary Report of the Evaluation of Uganda PRRO 6I76.oo: targeted food assistance for refugees, internally displaced persons and vulnerable Groups. WFP/EB.I/2002/5/2.

\section{Interviews (in date order)}

Male refugee participant during focus group discussion with members of the RWC III and other leaders, Odubu Centre, Rhino Camp, I5.8.2004.

Refugee Welfare Council III (RWC III) Chairman during focus group discussion with members of the RWC III and other leaders, Odubu Centre, Rhino Camp, I5.8.2004.

Refugee elder during focus group discussion with members of the RWC III and other leaders, Odubu Centre, Rhino Camp, I5.8.2004.

Group discussion with members of the RWC III and other leaders, Odubu Centre, Rhino Camp, I5.8.2004.

Advisor to the RWC III during focus group discussion with members of the RWC III and other leaders, Odubu Centre, Rhino Camp, I5.8.2004.

Male refugee, Ariwa V, Rhino Camp, I5.8.2004.

Young female refugee, Odubu II, Rhino Camp, I5·08·2004.

Young male refugee, Tika III, Rhino Camp, I6.8.2004.

Male refugee pastor, Tika II, Rhino Camp, I6.8.2004.

Headmaster, Tika Primary School, Tika II, Rhino Camp, I6.8.2004.

Member of a refugee cultural group during focus group discussion, Matangacia I, Rhino Camp, I6.8.2004.

Secretary to the RWC III, Imvepi Settlement, I7.8.2004.

Male refugee teacher, Imvepi SHSS, I8.8.2004.

Male refugee, Point E, Imvepi Settlement, I8.8.2004.

Office of the Prime Minister (OPM) Clerk, Imvepi Settlement, I8.8.2004.

Female Community Facilitator, Point B, Imvepi Settlement, I8.8.2004.

Male self-settled refugee, Imvepi Settlement, I9.8.2004.

Male refugee, Point E, Imvepi Settlement, 20.8.2004.

Female self-settled refugee, head of household, Awindiri village, 20.8.2004.

Male Sudanese self-settled refugee, Koboko County, 23.8.2004.

Male self-settled refugee, Ombachi, Koboko, 23.8.2004.

Self-settled Sudanese refugee family, Koboko County, 23.8.2004.

Young male self-settled refugee, Ombachi, Koboko, 23.8.2004.

Ugandan Parish Chief, Koboko County, 23.8.2004.

Group discussion with a group of young men in Kiryandongo, September 2004. 